Tropical Journal of Pharmaceutical Research July 2014; 13 (7): 1079-1084

ISSN: $1596-5996$ (print); 1596-9827 (electronic)

(C) Pharmacotherapy Group, Faculty of Pharmacy, University of Benin, Benin City, 300001 Nigeria.

All rights reserved.

Available online at http://www.tjpr.org

Original Research Article

http://dx.doi.org/10.4314/tjpr.v13i7.10

\title{
Protective Effect of (-)-Epigallocatechin Gallate against Photo-Damage Induced by Ultraviolet A in Human Skin Fibroblasts
}

\author{
Sohee Shin ${ }^{1}$, Liu-Xiang Wang ${ }^{1}$, Xin-Qiang Zheng ${ }^{1}$, Li-Ping Xiang ${ }^{2}$ and Yue-Rong \\ Liang $^{1 *}$ \\ ${ }^{1}$ Zhejiang University Tea Research Institute, Hangzhou 310058, ${ }^{2}$ Guizhou Tea and Tea Products Quality Supervision and \\ Inspection Center, Zunyi 563100, China
}

*For correspondence: Email: yrliang@zju.edu.cn; Tel/Fax: +86 57188982704

Revised accepted: 2 June 2014

\begin{abstract}
Purpose: To investigate the photoprotective effect of (-)-epigallocatechin gallate (EGCG), one of tea catechins, on human skin fibroblast (HSF) irradiated by ultraviolet $A$.

Methods: HSF cells were incubated in serum-free Dulbecco's Modified Eagle's Medium (DMEM) with or without EGCG for $2 \mathrm{~h}$, and then irradiated by UV A. Blank (control) was incubated in DMEM without EGCG and UV A-irradiation. Cell viability was determined by 3-(4, 5-dimethylthiazol-2-yl)-2, 5diphenyltetrazolium bromide (MTT) method. Protein concentration of the samples was determined using a PA102 Bradford protein assay kit. Malondialdehyde (MDA), glutathione peroxidase (GSH-Px) and superoxide anion radicals were determined using MDA assay kit, GSH-Px assay kit and superoxide anion radical assay kit, respectively.

Results: HSF viability decreased with dosage of UV A irradiation with $50 \%$ lethal dose (LD50) of 9 $\mathrm{J} / \mathrm{cm}^{2}$. Pre-incubation of HSF in $10 \mu \mathrm{g} / \mathrm{mL}$ EGCG aqueous solution for $2 \mathrm{~h}$ before exposure to UV A alleviated the suppressive effect of UV A on HSF. Compared to UVA irradiation alone, HSF viability and GSH-Px activity in the EGCG pretreatment increased by 18.3 and $103.4 \%$, accompanying decrease in level of superoxide anion radicals and MDA by 44.6 and $16.6 \%$, respectively.

Conclusion: EGCG alleviates UV A-induced HSF photo-damage through relieving oxidative stress by increasing activity of GSH-Px and scavenging capacity of superoxide anion radical.
\end{abstract}

Keywords: Irradiation, Catechins, Photoaging, Photoprotection, Malondialdehyde, Glutathione peroxidase, Superoxide anion radical

Tropical Journal of Pharmaceutical Research is indexed by Science Citation Index (SciSearch), Scopus, International Pharmaceutical Abstract, Chemical Abstracts, Embase, Index Copernicus, EBSCO, African Index Medicus, JournalSeek, Journal Citation Reports/Science Edition, Directory of Open Access Journals (DOAJ), African Journal Online, Bioline International, Open-J-Gate and Pharmacy Abstracts

\section{INTRODUCTION}

Human skin ageing is accelerated under external stress conditions such as ultraviolet (UV) irradiation and genotoxic agents. UV is a major environmental source of damage to the skin. The effect of UV on skin biology and immune system plays a major role in photoaging, inflammation and carcinogenesis [1]. Based on wavelength, solar UV can be divided into UV A (320-400 nm), UV B (280-320 nm) and UV C (<280 nm). High energy short wavelength UV $C$ is absorbed by the ozone layer and atmosphere, therefore it does not reach the Earth's surface. UV B can partially penetrate the ozone layer and it makes up 5-10 \% of atmospheric UV [2]. UV B has indirect detrimental effects on the immune system of the skin, oxidative stress responses, 
and photoaging [3]. UV A radiation is more than $90 \%$ of atmospheric UV irradiation [2], and it penetrates much deeper into the epidermis and dermis of the skin $[4,5]$.

UV A radiation is absorbed by DNA and reacts with non-DNA chromophores, leading to formation of reactive oxygen species (ROS) which damage DNA, proteins, and lipids in the skin $[4,5]$. UV A plays a significant role in producing genotoxic bipyrimidine photo-products [6]. In vivo human studies show that UV A irradiation also has immunosuppressive effects [7]. Chronic and excessive UV exposure depletes human cutaneous defense mechanisms [8]. Human exposure to UV A has become a public health concern [9].

Experiments in vivo and in vitro show that plant polyphenols enhance intracellular antioxidant defense and anti-inflammatory capacity, therefore they can be used as photo-protective and chemo-preventative agents $[4,10,11]$. Tea is an important dietary source of plant polyphenols in which (-)-epigallocatechin-3-gallate (EGCG) is the most abundant one (Figure 1). Green tea polyphenols have been found to be effective at alleviating UV B induced damages [12-15]. However, their ability to reduce UV-induced photodamage in humans in vivo has not been addressed [16], and the effect of EGCG on mutation and ageing of cultured human skin fibroblast (HSF) caused by UV A irradiation and its underlying mechanism remain unclear [17]. This study was undertaken to determine whether EGCG was able to limit UVA-induced photodamage in HSF cells.<smiles>O=C(O[C@H]1Cc2c(O)cc(O)cc2O[C@H]1c1cc(O)c(O)c(O)c1)c1cc(O)c(O)c(O)c1</smiles>

Figure 1: Molecular structure of (-)-epigallocatechin gallate (EGCG)

\section{EXPERIMENTAL}

\section{Materials}

The cell line used in the test was human skin fibroblast (HSF) purchased from the Cell Bank of
Chinese Academy of Sciences (Shanghai, China). Dulbecco's modified Eagle's medium (DMEM) and fetal bovine serum (FBS) were purchased from Thermo Fisher Scientific Inc. (New Hampshire, USA). EGCG (95\% purity) was supplied by CinoTea Ltd (Hangzhou, China). The other chemicals used were AR grade and were purchased from Sinopharm Group Corporation (Beijing, China).

\section{Cell culture and treatments}

HSF cells were cultured in $10 \mathrm{~cm}$ culture dish in DMEM supplemented with $10 \%$ FBS, penicillin $(100 \mathrm{IU} / \mathrm{mL})$ and streptomycin $(100 \mathrm{pg} / \mathrm{mL})$, at 37 ${ }^{\circ} \mathrm{C}$ in a humidified atmosphere containing $5 \%$ $\mathrm{CO}_{2}$. When confluence was attained at $80 \%$, the medium was disposed of, and the cells washed in phosphate buffered saline (PBS). The cells were then treated with EGCG aqueous solutions at concentrations $0,10,20$ and $40 \mu \mathrm{g} / \mathrm{mL}$ for $2 \mathrm{~h}$, and then irradiated by UV A using UV A lamps (Spectronics Corp. New York, USA) at dosage of $0,4.5,9.0$ and $13.5 \mathrm{~J} / \mathrm{cm}^{2}$, respectively. A blank control was incubated in serum-free medium without EGCG or UV A-irradiation.

\section{Cell viability assay}

The cell viability was determined by the ability of mitochondria to convert 3-(4, 5-dimethylthiazol-2yl)-2, 5-diphenyltetrazolium bromide (MTT) to formazan dye. The MTT was dissolved at a concentration of $5 \mathrm{mg} / \mathrm{mL}$ in PBS. The cells to be tested were cultured overnight onto 96-well plate at a density of $1 \times 10^{5}$ cells/well. $20 \mu \mathrm{L}$ of MTT solution was added to each culture well, and then the plates were incubated at $37{ }^{\circ} \mathrm{C}$ in an atmosphere of $5 \% \mathrm{CO}_{2}$ for $4 \mathrm{~h}$. The medium was replaced by dimethyl sulfoxide (DMSO) $(200 \mu \mathrm{L}$ per well), pipetting up and down until the crystals being dissolved. Absorbance of the samples was measured at $492 \mathrm{~nm}$ in an ELISA reader (Thermo Fischer Scientific, MA, USA). The results of cell viability were presented as the percentage of $492 \mathrm{~nm}$ absorbance of tested samples to that of the control.

\section{Biochemical assays}

Malondialdehyde (MDA) and superoxide anion radical were determined using MDA assay kit and superoxide anion radical assay kit (Jiancheng Sci-Tech Co. Ltd., Nanjing, China), respectively, according the manufacturer's guides. Activity of glutathione peroxidase (GSHPx) was determined using GSH-Px assay kit (Jiancheng Sci-Tech Co. Ltd., Nanjing, China) following the kit instruction and expressed as enzyme active unit per gramme of protein. The 
protein was tested using a PA102 Bradford protein assay kit [Tiangen Biotech (Beijing) Co., Ltd., Beijing, China] according to instructions of the kit.

\section{Statistical analysis}

Data were analyzed using Student's t-test and presented as mean \pm standard deviation (SD). $P$ $<0.05$ was regarded as statistically significant.

\section{RESULTS}

\section{Effect of UV A and EGCG on viability of HSF cells}

Viability of HSF cells was suppressed by UV A irradiation in a dose dependent manner (Figure 2). The lethal dosage $50 \%$ (LD50) at which viability of HSF cells decreased by $50 \%$ was about $9 \mathrm{~J} / \mathrm{cm}^{2}$. At the LD50, the HSF cells were seriously injured by UV A irradiation, but the cell viability could be partially recovered by UV protection armamentarium. Therefore, UV A irradiation dosage $9 \mathrm{~J} / \mathrm{cm}^{2}$ was used in the following experiments to test the effects of EGCG on UV A induced HSF damage. If the HSF cells were pre-incubated in EGCG aqueous solution for $2 \mathrm{~h}$ before exposed to $9 \mathrm{~J} / \mathrm{cm}^{2}$ UVA irradiation, the suppressive effect of UVA on the HSF was relieved (Figure 3). However, there was no significant difference in growth rate as the EGCG concentration increased from $10 \mu \mathrm{g} / \mathrm{mL}$ to $40 \mu \mathrm{g} / \mathrm{mL}$ (Figure 3). Based on this result, EGCG concentration $10 \mu \mathrm{g} / \mathrm{mL}$ was used in the subsequent tests.

The HSF cells were incubated in EGCG aqueous solution for $2 \mathrm{~h}$ before irradiated at $9 \mathrm{~J} / \mathrm{cm}^{2}$ UVA.

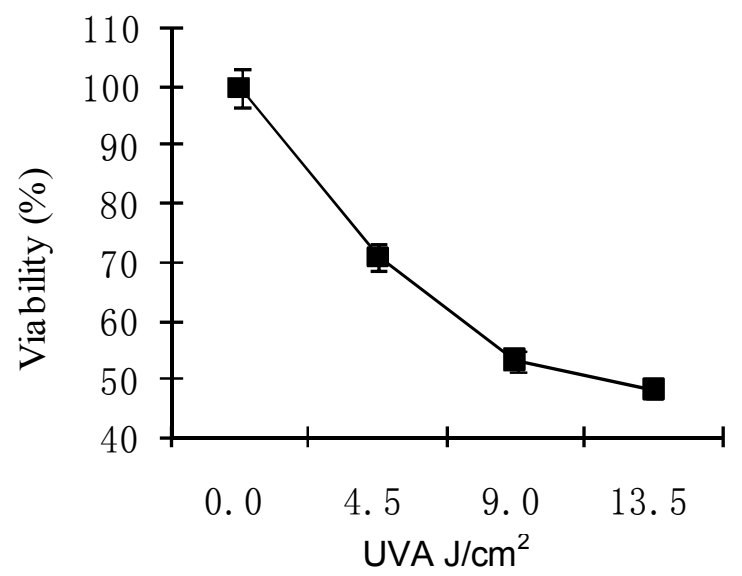

Figure 2: Effect of UVA irradiation on viability HSF cells

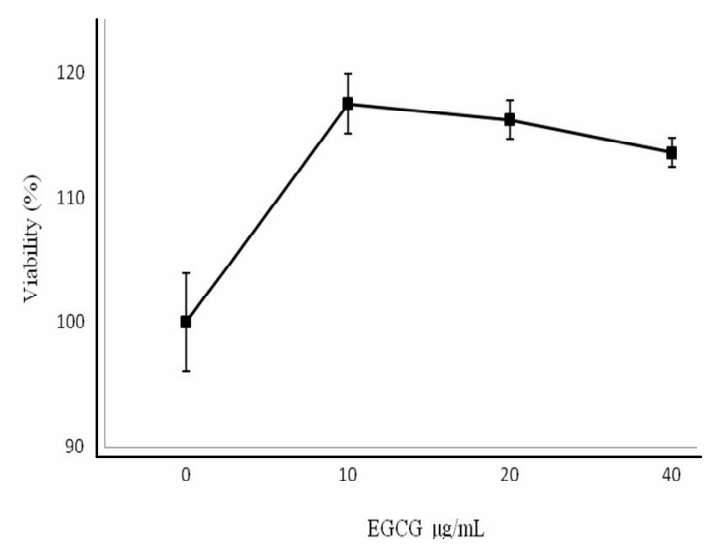

Figure 3: Effect of EGCG on viability of HSF cells exposed to UVA

\section{Effect of EGCG on some oxidative stress parameters of HSF cells exposed to UV A}

UV A irradiation $\left(9 \mathrm{~J} / \mathrm{cm}^{2}\right)$ significantly increased MDA level in the HSF cells. However, the UVAinduced increase in MDA level was suppressed by pre-treatment with EGCG $(10 \mu \mathrm{g} / \mathrm{mL})$ before exposure to UVA irradiation (UV A + EGCG). Figure 4 showed that MDA level of treatment (UV $A+E G C G)$ was $16.6 \%$ lower than UV A irradiation alone (UV A). MDA is an end product of lipid peroxidation. This suggests that EGCG has anti-lipid peroxidation activity, which results in decrease in MDA accumulation.

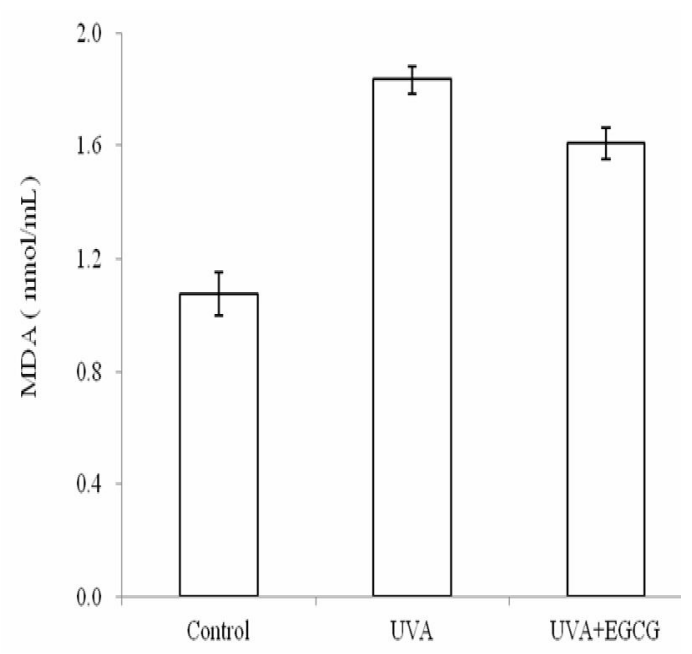

Figure 4: Effect of EGCG on MDA level in HSF cells exposed to UV A

Figure 5 shows that superoxide anion level increased when the HSF cells were exposed to 9 $\mathrm{J} / \mathrm{cm}^{2}$ UV A. However, the increase was suppressed as the cells were pre-incubated with EGCG $(10 \mu \mathrm{g} / \mathrm{mL})$ before exposed to UV A. The responses of GSH-Px to UV A irradiation and EGCG pre-treatment showed a reverse trend as 
the MDA level and the superoxide anion level (Figures 4-6).

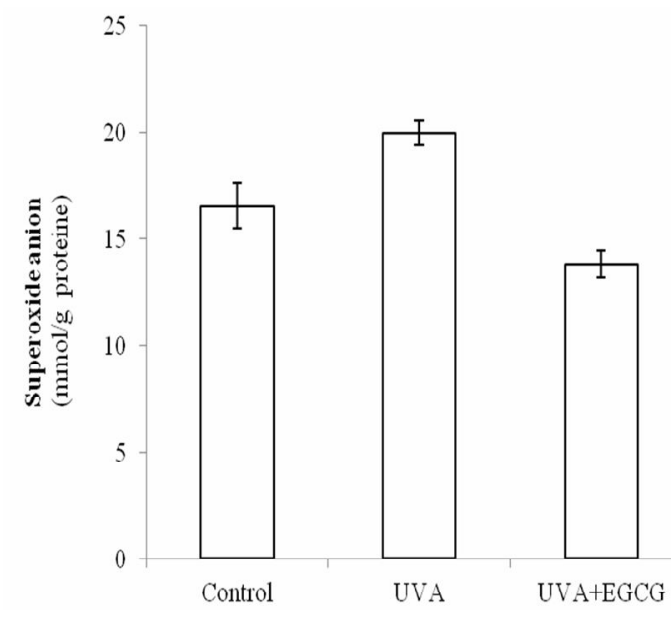

Figure 5: Effect of EGCG on superoxide anion level in HSF cells exposed to UVA

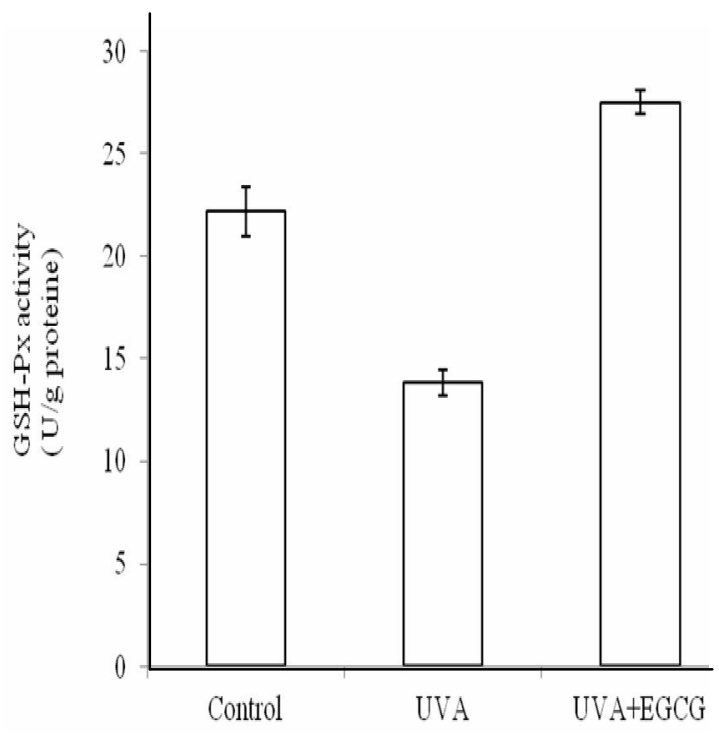

Figure 6: Effect of EGCG on GSH-Px activity in HSF cells exposed to UVA

\section{DISCUSSION}

UV radiations absorbed by the skin surface can produce harmful compounds called free radicals or reactive oxygen species (ROS), which are chemically reactive molecules containing oxygen such as oxygen ions and peroxides and can cause skin cancer and premature aging [18].The underlying mechanism of UV radiation damage is known to be the generation of ROS resulting from lipid peroxidation of the membranes in the skin cells [19-22]. Lipid peroxidation is one of the sequels of superoxide anion generation [23]. One possible method to prevent skin from UV damage is to use a powerful antioxidant to quench the generated ROS [24]. The results of this study showed that EGCG suppressed the increase in levels of superoxide anion and MDA of the HSF cells exposed to UV A (Figures 4-5), resulting in the increase of HSF viability (Figure 3 ). MDA is an end product of lipid peroxidation [23]. These suggest that EGCG, a potent free radical scavenger, is able to curtail the damaging effects of UV A by inhibiting the generation of superoxide anions and lipid peroxidation.

Glutathione peroxidase (GSH-Px) is an enzyme family with peroxidase activity whose biochemical function is to reduce lipid hydroperoxides to their corresponding alcohols and to reduce free hydrogen peroxide to water so as to protect the organism from oxidative damage. An investigation on the skin fibroblasts from subjects of different ages showed that GSHPx activity in the skin fibroblasts decreased with age, accompanying an increase in MDA level [20]. Hydrogen molecule $\left(\mathrm{H}_{2}\right)$ has been known as a safe antioxidant in the prevention and therapeutic approach towards several diseases. Bathing with hydrogen reduced water (HRW) before exposure to UV B significantly reduced the levels of skin damage induced by the UV B, accompanying significant increase in activity of GSH-Px [22]. Keratinocyte-specific knockout mice lacking the glutathione peroxidase 4 (GSHPx 4), an isoenzyme of GSH-Px, increased lipid peroxidation in cultured keratinocytes and whole skin [25]. Loss of GSH-Px 4 in the epidermis caused epidermal hyperplasia, dermal inflammatory infiltrate, dysmorphic hair follicles, and alopecia in perinatal mice [25]. The compound 6-CySeCD, a GSH-Px mimic, could relieve the damage induced by UV $B$ irradiation in HaCaT cells [26]. The present study showed that pre-treatment of EGCG alleviated the suppression of GSH-Px activity induced by UVA irradiation (Figure 6), which might be partially contributed to the lower levels of superoxide anion and MDA by reducing oxidative stress.

There was study showed that epicatechin (EC), one of green tea catechins, protected HSF cells against UVA-induced damages by its sunscreen and its effect on the synthesis of new proteins [27].The antioxidative activity of flavonoids are considered to be depended on the number of $\mathrm{OH}$ group in their molecules. The more $\mathrm{OH}$ groups it has, the stronger its power to fight against UV stressed skin aging [28,29]. EGCG is the ester of epigallocatechin and gallic acid, and so its molecule has more $\mathrm{OH}$ groups than $\mathrm{EC}$, thus making EGCG a stronger potential candidate as a dermatological protectant. 


\section{CONCLUSION}

The present study confirmed that UV A irradiation suppressed viability of human skin fibroblast (HSF) and pre-treatment of HSF with $10 \mu \mathrm{g} / \mathrm{mL}$ EGCG for $2 \mathrm{~h}$ before exposure to UV A alleviated the suppressive effect of UVA. The underlying mechanism for EGCG protecting HSF cells against UVA-induced photo-damage is considered to be its relieving oxidative stress by suppressing the UVA-induced decrease in glutathione peroxidase (GSH-Px) activity and inhibiting the UVA-induced increase in superoxide anion radicals, lipid peroxidation and malondialdehyde (MDA).

\section{ACKNOWLEDGEMENT}

This work was supported by National Key Technology R\&D Program in the 12th Five Year Plan of China (Project no. 2012BAD36B06-2).

\section{REFERENCES}

1. Hildesheim J, Fornace AJ. The dark side of light: the damaging effects of UV rays and the protective efforts of MAP kinase signaling in the epidermis. DNA Repair 2004; 3: 567-580.

2. Jacovides, CP, Tymvios FS, Asimakopoulos DN, Kaltsounides NA, Theoharatos GA, Tsitouri M. Solar global UVB (280-315 $\mathrm{nm})$ and UVA (315-380 nm) radiant fluxes and their relationships with broadband global radiant flux at an eastern Mediterranean site. Agric For Met 2009; 149: 1188-1200.

3. Wang L, Shirure VS, Burdick MM, Wu S. UVB irradiation regulates VLA-4-mediated melanoma cell adhesion to endothelial VCAM-1 under flow conditions. Mol Carcinogen 2011; 50: 58-65.

4. Li NN, Deng L, Xiang LP, Liang YR. Photoprotective effect of tea and its extracts against ultraviolet radiation-induced skin disorders. Trop J Pharm Res 2014; 13: 475-483.

5. Sage E, Girard PM, Francesconi S. Unravelling UVA induced mutagenesis. Photoch Photobio Sci 2012; 11: 74-80.

6. Douki T, Reynaud-Angelin A, Cadet J, Sage E. Bipyrimidine photoproducts rather than oxidative lesions are the main type of DNA damage involved in the genotoxic effect of solar UVA radiation. Biochem 2003; 42: 9221-9226.

7. Baron ED, Fourtanier A, Compan D, Medaisko C, Cooper $K D$, Stevens SR. High ultraviolet $A$ protection affords greater immune protection confirming that ultraviolet A contributes to photoimmunosuppression in humans. J Invest Dermatol 2003; 121: 869-875.

8. Sander CS, Chang H, Hamm F, Elsner P, Thiele JJ. Role of oxidative stress and the antioxidant network in cutaneous carcinogenesis. Intl J Dermatol 2004; 43:326-335.

9. Lim HW, James WD, Rigel DS, Maloney ME, Spencer $J M$, Bhushan R. Adverse effects of ultraviolet radiation from the use of indoor tanning equipment: time to ban the tan. J Am Acad Dermatol 2011; 64: 893-902.

10. Hong $Y H$, Jung $E Y$, Shin KS, Kim TY, Yu, KW, Chang UJ, Suh, HJ. Photoprotective effects of a formulation containing tannase-converted green tea extract against UVB-induced oxidative stress in hairless mice. Appl Biocheml Biotechnol 2012; 166: 165-175.

11. Amin ARMR, Kucuk O, Khuri FR, Shin DM. Perspectives for cancer prevention with natural compounds. J Clin Oncol 2009; 27: 2712-2725.

12. Zheng $X Q$, Jin J, Chen $H, D u Y Y, Y e J H, L u J L$, Lin $C$, Dong J, Sun $Q, W u L Y$, Liang YR. Effect of ultraviolet $B$ irradiation on accumulation of catechins in tea (Camellia sinensis (L) O. Kuntze). Afr J Biotechnol 2008; 7: 3283-3287.

13. Lee $X Z$, Liang $Y R$, Chen $H$, Lu JL, Liang HL, Huang FP, Mamati EG. Alleviation of UV-B stress in Arabidopsis using tea catechins. Afr J Biotechnol 2008; 7: 41114115.

14. $X u$ JY, Wu LY, Zheng $X Q$, Lu JL, Wu MY, Liang YR. Green tea polyphenols attenuating ultraviolet $B$ induced damage to human retinal pigment epithelial cells in vitro. Invest Ophth Vis Sci 2010; 51: 66656670.

15. Wu $L Y$, Zheng $X Q$, Lu JL, Liang YR. Protective effect of green tea polyphenols against ultraviolet B-induced damage to HaCaT cells. Human Cell 2009; 22:18-24.

16. Elmets $C A$, Singh $D$, Tubesing $K$, Matsui $M$, Katiyar $S$, Mukhtar $H$. Cutaneous photoprotection from ultraviolet injury by green tea polyphenols. J Amer Acad Dermatol 2011; 44: 425-432.

17. $X u$ Y, Zhu J, Zhou BR, Luo D. Epigallocatechin-3-gallate decreases UVA-induced HPRT mutations in human skin fibroblasts accompanied by increased rates of senescence and apoptosis. Exp Ther Med 2012; 3: 625-630.

18. Comelekoglu U, Yalin S, Balli E, Berkoz M. Ovariectomy decreases biomechanical quality of skin via oxidative stress in rat. Turk J Med Sci 2012; 42: 201-209.

19. Shang $Y$, Zhang $L$, Jiang $Y T$, Li $Y$, Lu P. Airborne quinones induce cytotoxicity and DNA damage in human lung epithelial $A 549$ cells: The role of reactive oxygen species. Chemosphere 2014; 100: 42-49.

20. Lu CY, Lee HC, Fahn HJ, Wei YH. Oxidative damage elicited by imbalance of free radical scavenging enzymes is associated with large-scale mtDNA deletions in aging human skin. Mutat Res-Fund Mol M 1999; 423: 11-21.

21. Sachdeva $M$, Kharya $M$, Aljarbou A, Katyal $T$. Photoprotective effects of hydroalcohol Tagetes erectus extract against UV-induced oxidative damage in mice. Trop J Pharm Res 2011; 10: 747-753. 
22. Ignacio RM, Yoon YS, Sajo MEJ, Kim CS, Kim DH, Kim SK, Lee KJ. The balneotherapy effect of hydrogen reduced water on UVB-mediated skin injury in hairless mice. Mol Cell Toxicol 2013; 9: 15-21.

23. Maharaj DS, Glass BD, Daya S. Exposure of rat skin homogenate to UV light in the presence of melatonin reduces lipid peroxidation and superoxide anion generation. Biogenic Amines 2001; 16: 531-540.

24. Mishra AK, Mishra A, Chattopadhyay P. Herbal cosmeceuticals for photoprotection from ultraviolet $B$ radiation: A Review. Trop J Pharm Res 2011; 10: 351-360.

25. Sengupta A, Lichti UF, Carlson BA, Cataisson C, Ryscavage AO, Mikulec C, Conrad M, Fischer SM, Hatfield DL, Yuspa SH. Targeted disruption of glutathione peroxidase 4 in mouse skin epithelial cells impairs postnatal hair follicle morphogenesis that is partially rescued through inhibition of COX-2. J Invest Dermatol 2013; 133: 1731-1741.

26. Li X, Zhang L, Xu YW, Wang C, Zhao Y, Yu P, Lv SW, Yan GL, Liu JQ, Luo GM. The protective effects of 6-
CySeCD with GPX activity against UVB-induced injury in HaCaT cells. Austral J Dermatol 2013; 54: 120-125.

27. Basu-Modak S, Gordon MJ, Dobson LH, Spencer JPE, Rice-Evans C, Tyrrell RM. Epicatechin and its methylated metabolite attenuate UVA-induced oxidative damage to human skin fibroblasts. Free Radical Biol Med 2003; 35: 910-921.

28. Sim GS, Lee BC, Cho HS, Lee JW, Kim JH, Lee DH, Kim $J H$, Pyo HB, Moon DC, Oh KW, Yun YP, Hong JT. Structure activity relationship of antioxidative property of flavonoids and inhibitory effect on matrix metalloproteinase activity in UVA-irradiated human dermal fibroblast. Arch Pharm Res 2007; 30: 290298.

29. Mishra AK, Mishra A, Chattopadhyay P. Herbal cosmeceuticals for photoprotection from ultraviolet $B$ radiation: A review. Trop J Pharm Res 2011; 10: 351360. 